International Journal of Social Science and Economic Research

ISSN: 2455-8834

Volume:05, Issue:10 "October 2020"

\title{
THE GEOGRAPHY OF ENTREPRENEURSHIP: COMPARISON OF SOUTH EAST ASIA AND AFRICA
}

\author{
Beverlley Madzikanda*, Cai Li and Francis Tang Dabuo \\ School of Management, Jiangsu University, 301 Xuefu Road, Zhenjiang City, Jiangsu, China \\ *Corresponding Author, Tel: +8615695110817
}

DOI: 10.46609/IJSSER.2020.v05i10.017 URL: https://doi.org/10.46609/IJSSER.2020.v05i10.017

\begin{abstract}
The quantity and quality of entrepreneurs is not evenly spread across the world. Some places have more than others while some focus on high-tech innovative business models and others focus on retail and trading. This study sought to single out the main factors that influence entrepreneurs' location decisions, what draws them to an area and what makes them reluctant to settle in other areas. The study focuses on continental regions, comparing South East Asia and Africa. It was found that entrepreneurs favor their home countries and countries which offer the best opportunities for them and their businesses. Countries were institutional procedures and infrastructure is advanced and fiscal policies encourage entrepreneurship have larger populations of entrepreneurs. Furthermore, prevailing educational, socio-cultural and political conditions will guide the types and levels of entrepreneurship which people will get involved in.
\end{abstract}

Keywords: Africa entrepreneurship, Asia entrepreneurship, economic geography entrepreneurship, entrepreneurship theory.

\section{Introduction}

In the 18th and 19th centuries the spatial positioning of businesses determined by transport routes and access to raw materials. We have come a long way since then. The location of businesses today is affected by a plethora of factors, globalization (Etemad \& Wright, 2003), politics (Johnson, Kaufmann, \& Shleifer, 1997), economic markets (Herrera-Echeverri, Haar, \& Estévez-Bretón, 2014), the internet and the rise of Industry 4.0 (Reuber \& Fischer, 2011). Entrepreneurship itself has disrupted traditional business models with many innovative and information-based solutions. This paper seeks to examine how entrepreneurship activities have subsequently affected economic geography in different parts of the world. The beauty of Industry 4.0 and Logistics 4.0 is that products can be made in a fraction of the traditional time and travel around the world in a few days sometimes even seconds, in the case of electronic goods and services. This is because many new ventures now rely fully or partially on digitized functions 


\section{International Journal of Social Science and Economic Research}

ISSN: $2455-8834$

Volume:05, Issue:10 "October 2020"

and often require a small input for a disproportionately larger output. And as a result, many business models see increasingly fewer benefits to locating in spatial proximity to their customers and are beginning to favor multi-location teams (Devezas \& Sarygulov, 2017). It is not uncommon to find a firm, headquartered in one city, have a strategy office is different remote city, a production plant on another continent and servers in yet another part of the world; but seamlessly work to provide quality goods and services made by pioneering business owners.

So, if raw materials, office space and localized proximity to suppliers and/or customers are no longer binding factors for the location of entrepreneurial activities, what therefore drives entrepreneurs to set up shop where they do? Previous literature and data made available by the (WorldBank, 2019), shows that entrepreneurial activity is not uniformly dispersed across the regions of the world. Why is it that some countries have more entrepreneurial ventures than others? To answer these questions this study employed data from some of the best and worst performing regions in entrepreneurship ranking, particularly Asia and Africa. These 2 regions make for intriguing case studies because one region has had a massive entrepreneurial wave in the last decade and one is on has promising signs of a highly lucrative trend on the horizon fueled by the internet and technology.

South East Asia had a Ease of doing business (DB) score of 63.3 out of 100 in 2018 with countries recording healthy numbers of newly listed entrepreneurial activities with the highest being India having 123942 in the first quarter of 2018 and followed by the Republic of Korea with 96155 which majority of these being High-tech and internet startups (GEM, 2019). What conditions are making entrepreneurship flourish here in recent years? Africa on the other hand had a DB score of 51.8 in the same year with countries showing a fairly high and a fairly low number of newly registered ventures with the 2 largest economies South Africa and Nigeria having 376727 and 86309 respectively while Zambia and Rwanda have some of the lowest even in the world at 10236 and 10635 majority of which are retail and replicative entrepreneurship (Adusei, 2016). The lowest number of new ventures of the countries studied in this paper for Asia was 29 243, almost 3 times the lowest in Africa. Clearly there are differences in the regions in the quantity and quality of entrepreneurs and it should be noted that some of these entrepreneurs are not natives of those countries but have made a choice to migrate there. This study will take a dive into the black box of entrepreneurs, data and literature of economic geography to find out what are the main factors that determine where entrepreneurs choose to set up their new ventures. The aims of the study are to clearly show how entrepreneurial activity is different in the two regions, determine why these differences exist and finally ascertain how different countries are facilitating the growth and maintenance of their respective levels of TEA, total entrepreneurial activity.

\section{Literature Review and Theoretical foundation}




\section{International Journal of Social Science and Economic Research}

ISSN: $2455-8834$

Volume:05, Issue:10 "October 2020"

To begin to understand why entrepreneurs locate where they do, we must first outline who and what we will consider as entrepreneurship in this study. (Dau \& Cuervo-Cazurra, 2014) define entrepreneurship as the establishing of a "new, stable business venture" that makes use of new business models and innovation in its processes. We must clearly define the difference between entrepreneurs and small business owners, of which the latter are more prevalent in the least developed areas of both regions. Small business owners concentrate on survival, making sales and achieving profit targets while delivery the same goods and services (Burger, O'Neill, \& Mahadea, 2005) . Entrepreneurs are distinctly different as their strategic targets are to not just survive but to grow and expand through innovation of products, service delivery, production methods and organization structures(Nieman \& Pretorius, 2004). These creative risk takers who bear uncertainty will be the main consideration of this study. This definition will be the working definition of this study. We explore the link between entrepreneurship and institutional theory.(Klapper, Amit, Guillén, \& Quesada, 2007) and (Adusei, 2016) explain that there are formal and informal entrepreneurs where the former has a legally registered firm in the formal sectors and the latter is not registered under the law and is otherwise unregulated but provides legal goods and services. Informal sector players proved to be a challenge in terms of obtaining data so only formal entrepreneurs were considered for this study. These scholars went on the describe that entrepreneurs can be innovative; meaning they make use of ICT and technology in their operation or are pioneering a service or good, or they can be replicative in which case they engage in solely trade businesses or generic business models which are already in existence. All these set the administrative, legal and socio-cultural environment in which entrepreneurs must exist, affected by all the factors albeit to a varying degree.

(Audretsch, Keilbach, \& Lehmann, 2006) describes the motivations behind entrepreneur actions as being either influenced by external factors (exogenous) or influence by the internal advantages of the firm or the individual (endogenous). It is deduced that many endogenously motivated players are involved in knowledge intensive industries such as ICT, telecommunications, biotech and other tech related industries who are more often than not a result of knowledge spillovers from other organizations. In respect to the geography of these firms, it was noted that because these companies have a "source of knowledge", they may most likely be located withing close proximity of this organization.

\section{Determinants of the geography of entrepreneurs}

(Audretsch et al., 2006) argues that the location of entrepreneur's is determined by finance and population and unemployment. In the book, the author stands to say that entrepreneurs choose where to locate based on where they have access to finance for their company and access to a skilled labor force. He also says that Internet and tech companies have the same needs but on a global scale. Furthermore ,the knowledge spillover theory(Agarwal, Audretsch, \& Sarkar, 2010) 


\section{International Journal of Social Science and Economic Research}

ISSN: $2455-8834$

Volume:05, Issue:10 "October 2020"

suggests that many entrepreneurial ventures are either spinoffs, spillovers or startups which are all different but do get all or part of their business model or expertise from other organizations they were once involved with (Steven Klepper, 2001). These can be other companies in the same industry or even universities that make use of ideas that were otherwise uncommercialized, and this is especially true for tech startups. For these companies they often choose to locate within close geographic proximity to their parent organization. This gives the new firms post startup assistance with the innovation process, a competitive advantage over other firms without guidance, managerial and technology support and resource coordination (Agarwal et al., 2010; Feldman \& Francis, 2002; Naudé, 2011), and even unmatched access to human capital and highly skilled labor that is well trained for the jobs needed (Bloom \& Van Reenen, 2010; Schwab, 2015). This can lead to clustering of companies.

In traditional cluster theories, it is well documented that traditionally firms in the same industry often clustered in the same location on account of proximity to natural resources, production externalities, pecuniary economies and proximity to previous work, school and even hometown (Buenstorf \& Klepper, 2010; Delgado, Porter, \& Stern, 2010; Dumais, Ellison, \& Glaeser, 2002; Stuart \& Sorenson, 2003). However, new entrepreneurs do not always conform to these. (Autio, Nambisan, Thomas, \& Wright, 2018) put forward the idea of knowledge clusters which is the conglomeration of entrepreneurs in that stand to synergize entrepreneurial ecosystems in traditionally unrelated areas but are being brought together by the power of internet, shared technology and big data. An example given was Silicon Valley in the USA. (Zou \& Liang, 2015) and (Delgado et al., 2010) corroborate this by bringing to light the entrepreneurial clusters, known as Taobao Villages in rural China, of unrelated rural business whose only common denominator is their use of e-commerce platform Taobao for sales.

Taking a more global perspective on this, studies show that entrepreneurs will tend to choose to locate where the entrepreneurial ecosystem is more developed and provides better opportunities their business. (Naudé, 2017) states that be most ideal ecosystem prerequisites that entrepreneurs need is contract enforcement, property rights, access to finance, fast and reliable internet, a skilled workforce and a dynamic economic environment for startups. (Atiase, Mahmood, Wang, \& Botchie, 2018) agree and state that in addition to these factors, entrepreneurs look out for access to reliable electricity and stable political governance. So, this is to say economic factors play a role in entrepreneurs choosing where to locate. (Brixiová \& Kangoye, 2016) makes reference to some socio-cultural factors in Africa that disadvantage women in entering the entrepreneurship arena, meaning cultural practices may affect the number of entrepreneurs within a geographic setting.

\section{Comparing Entrepreneurship in Africa and Asia}




\section{International Journal of Social Science and Economic Research}

ISSN: $2455-8834$

Volume:05, Issue:10 "October 2020"

Asia was once in the position that Africa is in today, with growing populations and underdeveloped technological capacities. But great strides have been made over the last 40 years and many economies in S.E Asia emerging as some of the leading world economies (Zhang \& Dodgson, 2014). Looking through the literature it was found that there are some differences that account for the ever-growing gap between the two regions in terms of entrepreneurial activity and innovation. A study into the innovation policies in China by (Reshetnikova, 2018) revealed that there is an extensive nationwide innovation strategy being spearheaded by government incentive, VC funding, angel investors and is fully supported by the governments' R\&D strategy. This means the central government is actively encouraging citizens to participate in entrepreneurial activities and providing the financial and infrastructure a support needed ( $\mathrm{He}, \mathrm{Lu}$, \& Qian, 2019). An account by (Naudé, 2017) provides a contrast by stating "African governments rarely promote indigenous [entrepreneurs], provide VC funds or encourage partnerships with foreigners".

Larger Asian economies are defined as moving into tech and innovation economies which are fueled by stable ICT infrastructures and large number of educated and skilled employees in STEM fields (Henry, 2007). Africa on the on the other hand accounts for only $1 \%$ of the global STEM research fields output and this number is on the decline (Prince \& Fantom, 2014). It is noted that many African countries' entrepreneurs are self-employed small business owners who operate primarily trade, health and natural resource-oriented ventures that are often small and rarely grow(Atiase et al., 2018). Asian counterparts seem to operate at an advantage with knowledge intensive and innovation-oriented ventures backed by healthy entrepreneurial ecosystems, higher education levels and advanced telecommunication and ICT infrastructures.(Bloom \& Van Reenen, 2010) state that strong education and business training and 21st century skills are just as important as technology infrastructure to building a competitive start-up and, in this case, Asia has both. These don't only apply to natives but immigrant entrepreneurs too. (Liu, Ye, \& Feng, 2019) describe the age-old phenomenon of rural - urban migration in China for better opportunities. Taking this on a global scale, immigrants also move from lesser developed countries to more developed ones in search for better opportunities for their businesses and Afro-Sino migration to cities like Guangzhou (Castillo, 2014) is proof of this.

Therefore, it is the conclusion of this review of literature that the choice of entrepreneurs to locate in certain geographic areas is influenced by prevailing economic, environmental and in some instances socio-cultural factors. There is also the need to be in close proximity to other organizations for several reasons and the availability of appropriate institutional infrastructures and amenities. It is also the opinion of many scholars that Asian countries considered here provide these factors more abundantly and widely than do the African countries considered. 


\section{Factors affecting the location choice of entrepreneurs}

Considering the literature review and data compiled by the researcher the major factors that directly and indirectly influence, fully explained in Appendix 1. The resultant influences of the location decision of entrepreneurs are illustrated in the model below.

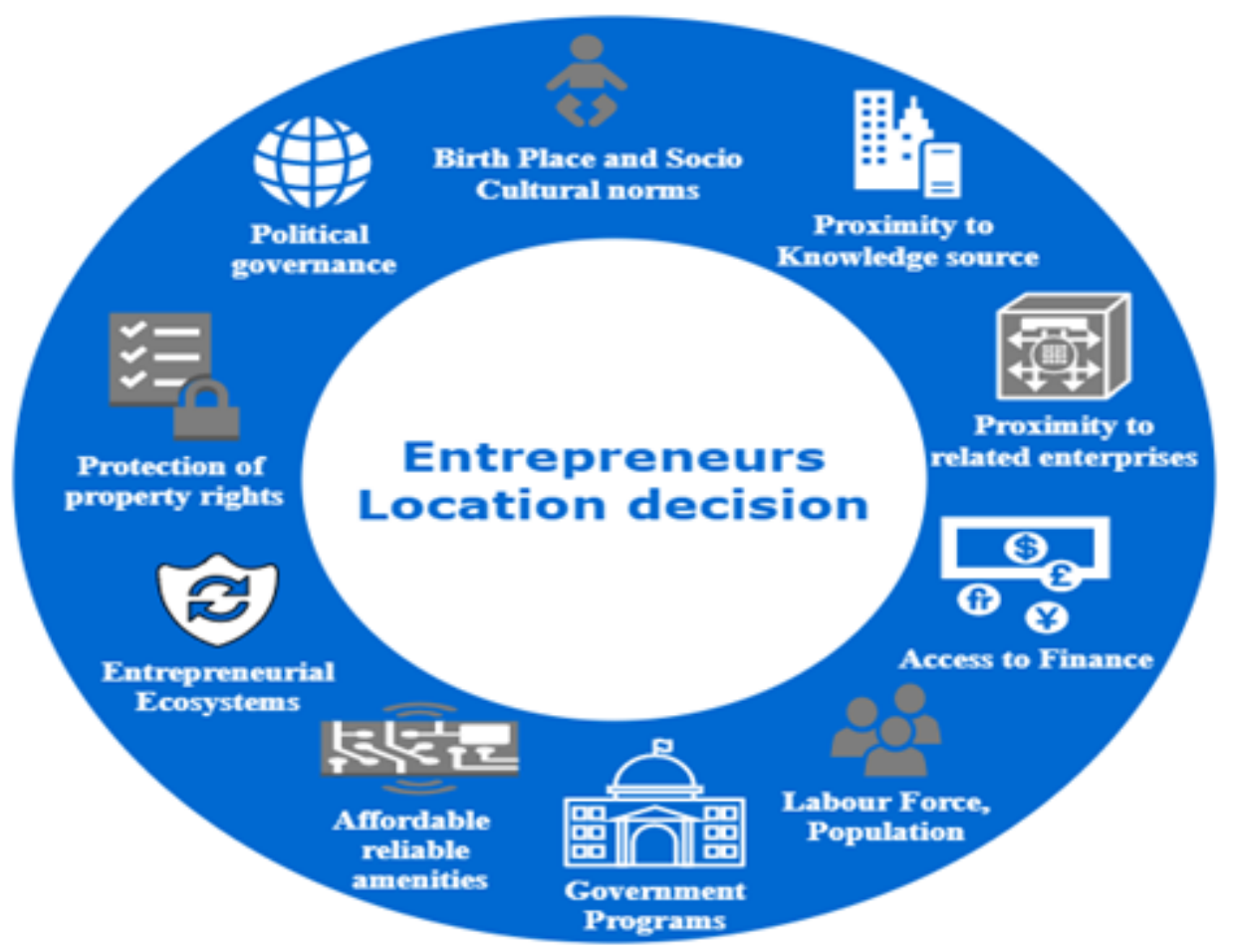

Figure 1: Illustration of the factors affecting entrepreneurs location decisions. (Illustrated by author)

The model shows the factors that surround the location decision for entrepreneurs and simultaneously cites the possible reasons why there are different levels of entrepreneurship in different regions. Basing on the factors, data from 6 African and 6 S.E Asian countries was collected and compared to see if indeed these factors influence the entrepreneurial levels of these regions and to what extent they account for the differences.

\section{Materials and Methodology}

In order to investigate whether the cited variables hold up in reality, cross-sectional data from the 2 regions in the year 2019/2018 were collected and examined. These are collected from international databases, the World Bank indicators and Global Entrepreneurship Monitor, both of which standardize the data across all countries to allow for comparison. The data consists of 


\section{International Journal of Social Science and Economic Research}

ISSN: $2455-8834$

Volume:05, Issue:10 "October 2020"

various indicators of the business environment, country profiles and other related statistics. It was compiled from various data banks and listed in Table 1. These were used to deduce certain conditions entrepreneurs face across geographic regions and also to ascertain whether these conditions presented by governments, investors and populations at large in these places are conducive to the settlement of entrepreneurs. The paper will go on to give several theoretical conclusions regarding these observations. It was also anticipated that identifying the differences in the regions would further explain why some regions are more entrepreneurially-oriented than others. According to the availability of the data, a random sample of 6 countries from each region was chosen for this study and these were namely; South Africa, Ghana, Uganda, Botswana, Algeria and Ethiopia from Africa, and China, India, Republic of Korea, Malaysia, Thailand and Indonesia from South East Asia.

\section{Discussion of evidence}

The total entrepreneurial activity (TEA) represents the percentage of the working age 18-64 population that are actively involved in business start-ups, either in the phase of starting a new firm (nascent entrepreneurs), or in the phase spanning 42 months after the birth of the firm. This value is the basis to determine the levels of entrepreneurial activity in the countries in this study. As previously observed, the Asian counterparts in this study have larger populations, while some African countries have very small populations. Therefore, the exact number of entrepreneurs in each country was computed in millions (M) to give meaning to subsequent interpretations. They are : China85.6M, South Korea 5.6M, India135.6M, Indonesia 25.6M, Malaysia 4.7M, Thailand 9.7M South Africa 4.1M, Botswana 0.4M, Uganda7.7M, Ghana 4.5M, Algeria 1.3M and Ethiopia 9M. It is clear that the Asian countries exhibit much larger TEA totals than do the African ones. Therefore, the main assumption of this study is that the Asian countries are the affirmative sample being the better geographical location for entrepreneurs since there is a larger number of them there as of this data in 2018.

New business density describes the number of newly registered businesses per 1000 people in a country. In Asia, the highest recorded value was Korea with a density of 2.6 while that of Africa was Botswana with 20.1. It should be noted that the population of Botswana is 2.3 million meaning the approximate number of new entrepreneurial ventures registered is 46230 . In comparison Korea has a population of 51.26 million bringing the approximate number of new ventures to 133276 , meaning it has a much larger ,about 3 time the highest in Africa, number of total new businesses. On average Asian countries have bigger populations than African countries, meaning business density might look smaller but the total number of new businesses registered in Asia will be much larger. Combining the conclusions of both these indicators, it can be deduced that averagely there are more entrepreneurial activity in S.E Asia than there is in Africa. Let us dive a little deeper to find out why this is the case. 
International Journal of Social Science and Economic Research

ISSN: 2455-8834

Volume:05, Issue:10 "October 2020"

Table 1: Economic Indicators of entrepreneurship

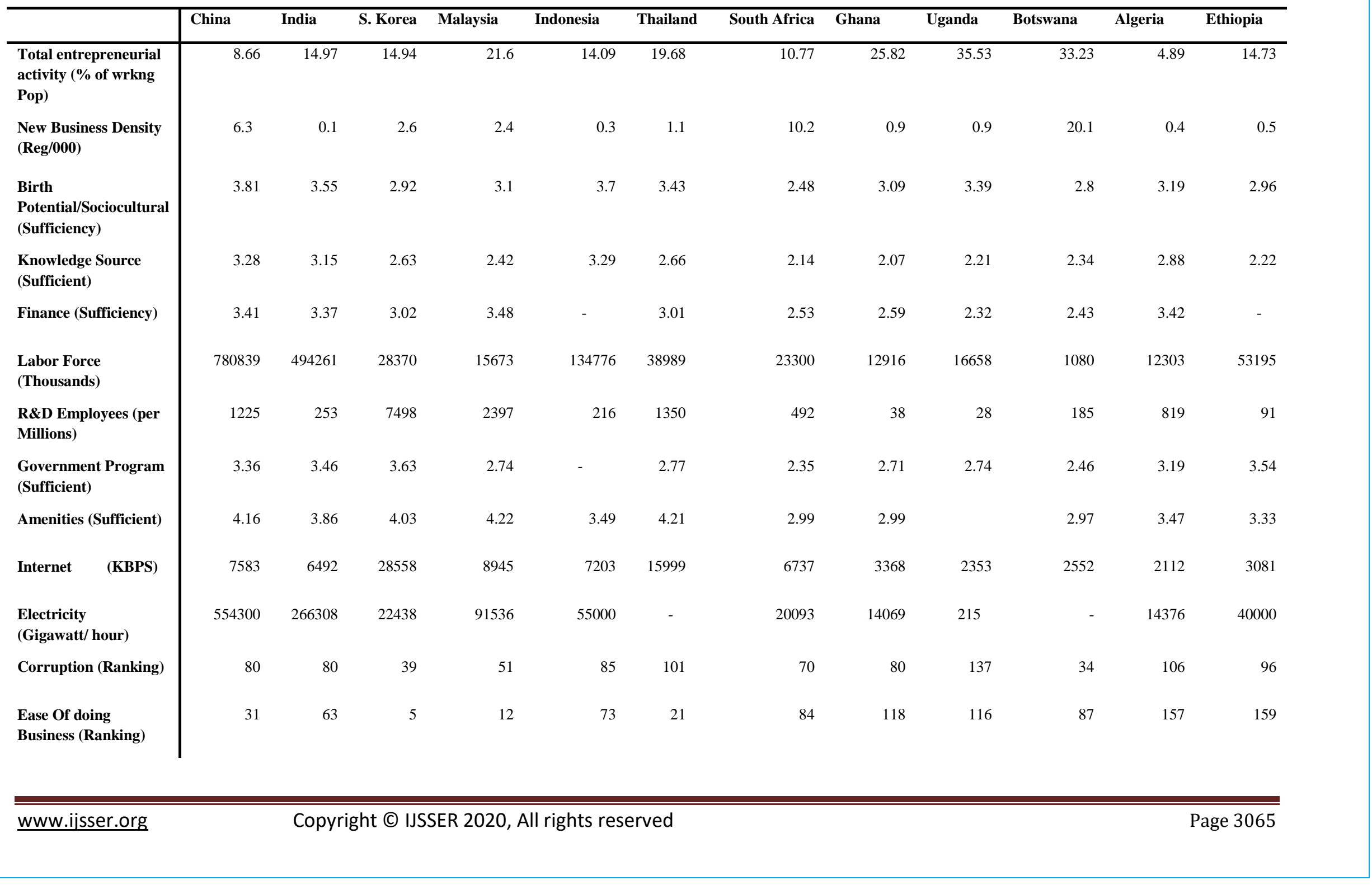


International Journal of Social Science and Economic Research

ISSN: 2455-8834

Volume:05, Issue:10 "October 2020"

\begin{tabular}{|c|c|c|c|c|c|c|c|c|c|c|c|c|}
\hline $\begin{array}{l}\text { Start Procedures } \\
\text { (Days) }\end{array}$ & 4 & 10 & 3 & 8 & 11 & 5 & 7 & 8 & 13 & 9 & 12 & 11 \\
\hline $\begin{array}{l}\text { Time to Start } \\
\text { (Days) }\end{array}$ & 9 & 18 & 8 & 18 & 13 & 6 & 40 & 13 & 24 & 48 & 18 & 32 \\
\hline $\begin{array}{l}\text { Government } \\
\text { Procedures } \\
\text { (Days) }\end{array}$ & 0.9 & 1.9 & 0.1 & 3.1 & 0.9 & 4.8 & 5.9 & 4 & 6.5 & 10.2 & 25.1 & 11.9 \\
\hline $\begin{array}{l}\text { Protect IPR } \\
\text { (Sufficient) }\end{array}$ & 3.2 & 3.34 & 2.73 & 2.98 & 3.02 & 3.24 & 2.72 & 3 & 3.09 & 2.5 & 2.86 & 2.67 \\
\hline $\begin{array}{l}\text { Government Policy } \\
\text { (Sufficient) }\end{array}$ & 3.18 & 3.25 & 3.18 & 2.68 & 3.12 & 2.67 & 2.1 & 2.29 & 2.54 & 2.45 & 2.75 & 2.62 \\
\hline
\end{tabular}

(Units)

Data compiled from (GEM, 2019; WorldBank, 2019) 
International Journal of Social Science and Economic Research

ISSN: $2455-8834$

Volume:05, Issue:10 "October 2020"

\section{Birth Potential and Socio-Cultural factors}

(TheKauffmanInstitute, 2019) says that $0.32 \%$ of the population are self-employed entrepreneurs. It therefore stands to argue that places with larger populations (birth potential) are predisposed to having a proportionately higher number of total entrepreneurs, so the number of those who will locate in their ventures in their country of birth and sometimes even their hometowns is higher (Dahl \& Sorenson, 2009; Figueiredo, Guimaraes, \& Woodward, 2002; Michelacci \& Silva, 2007). The population of China alone is almost the same as that of the whole of Africa, therefore the number of entrepreneurs will also be higher than those in Africa. In addition to the birth potential, socio-cultural factors that play into location of entrepreneurs. These include the societal and cultural view of entrepreneurship. The Global Entrepreneurship Monitor says that cultures that have a positive outlook towards entrepreneurship and encourage it can lead to larger entrepreneurship populations. It says that some societies view entrepreneurship as a suitable career choice, and in these societies there a generally more entrepreneurs(Ferreira \& Fernandes, 2015). The data shows that China and Indonesia have highly sufficient socio-cultural support for entrepreneurs and support the entrepreneurial activities with a rating of 3.81 and 3.70. Uganda and Algeria also have acceptably highly sufficient socio-cultural support at 3.39 and 3.19. The average ranking of Africa is lower than that of Asia and this partly explained by (Halkias, Nwajiuba, Harkiolakis, \& Caracatsanis, 2011) whose study of entrepreneurs in Nigeria showed that there is often a mistrust of entrepreneurship within one's own community and there is limited financial support from friends and family in startups. It also confirms another study (Brixiová \& Kangoye, 2016)showed that there is still discouragement of female entrepreneurs with some societies in Swaziland and South Africa believing women should be homemakers rather than self-employed entrepreneurs. One trait shared by both regions is that although entrepreneurship is viewed as a good career choice in some countries, other countries still encourage the youth to aspire for a government job or an industry position rather than take the risk of taking on an entrepreneurial venture which may or may not succeed.

Proposition 1a: Countries with larger populations proportionately have large population of entrepreneurs.

Proposition 1b: Countries with cultures that positively view entrepreneurship will have a larger percentage of people starting entrepreneurial ventures.

\section{Proximity to knowledge sources}

For those entrepreneurs in innovation-based companies, it is worthwhile to locate within close geographic proximity to a knowledge source. These can be parent companies, previous work places and universities that serve as a foundation of technical knowledge, $R \& D$, human and social capital. For this reason, several studies have concluded that many entrepreneurial 


\section{International Journal of Social Science and Economic Research}

ISSN: $2455-8834$

Volume:05, Issue:10 "October 2020"

activities are located close to their knowledge source(Agarwal et al., 2010; Agarwal, Echambadi, Franco, \& Sarkar, 2004). Places with existing innovative companies and strong research universities will attract as well as produce more entrepreneurs. The data reveals that China, India and Indonesia's entrepreneurs have the most sufficient access to knowledge sources with an index higher than 3.0. This may be due to the fact that these countries have more innovative companies as well as a large number of highly ranked universities that serve as knowledge sources. The smaller values were presented by Ghana and South Africa which suggests in these countries, innovative entrepreneurs have less sufficient access to quality commercial opportunities that come as a result of location within close proximity to a knowledge source. It means there is a proportionately smaller number of innovative companies and universities that produce scientific research work as compared to other countries with higher levels of sufficiency like Algeria and Korea. This supports findings of (Audretsch et al., 2006)and the theory of knowledge spillover (Ghio, Guerini, Lehmann, \& Rossi-Lamastra, 2015).

Proposition 2: A large concentration of innovative knowledge sources will result in a proportionately large number of innovative entrepreneurial ventures.

\section{Proximity to similar or related industries}

Cluster are especially common, either due to specially allocated office space in designated office and technology parks as is the case in China or entrepreneurial clusters based on collaboration (Audretsch, 2018; Autio et al., 2018; S Klepper \& Sleeper, 2000). These clusters bring about reduction in fixed costs, bigger and regular supply of entrepreneurs as well as proximity to capital (Glaeser, Kerr, \& Ponzetto, 2009). This factor is related to the proximity to knowledge source in that it requires a formidable entrepreneur population to pre-exist before it affects the location decision of new entrepreneurs. It can also be affected by the availability of other attractive incentives such as financial incentives or a geographical feature that facilitates the business as in the case of the Yangtze Valley in China ,a river that can cheaply transport raw materials needed for manufacturing (Glaeser et al., 2009). This factor cannot be easily evaluated to compare for the two regions, however countries with large numbers of existing firms like India and Algeria attract new entrepreneurs while countries with natural features and resources give way to entrepreneurial activities like large coastlines in India, Malaysia, South Africa and Ethiopia will also be a prime location choice for entrepreneurs.

Proposition 3: In a cluster of similar or related industries, knowledge sharing and spillover will result in many spin-off and start-up entrepreneurial ventures.

\section{Finance}

The topic of starting capital was cited by (Ekpe, Mat, \& Razak, 2010) as one of the leading causes for entrepreneurs in Nigeria being unable to start their own companies. It stands to reason 


\section{International Journal of Social Science and Economic Research}

ISSN: $2455-8834$

Volume:05, Issue:10 "October 2020"

that wherever entrepreneurs have access to government or private funding, they will choose to locate there ,proximity to capital. Data compiled from the (GEM, 2019), reveals that Malaysia, Algeria and China provide the most sufficient financial support for entrepreneurs. Algeria has one of the most favorable entrepreneurial scenes on the continent and access to funding is one of the main reasons why. China has a similar phenomenon, since 2013 where the government began providing major funding as well as encouraging investors to finance tech and innovation startups, there has been an overwhelming number of new businesses registered further showing that entrepreneurs are drawn to unimpeded finance. With governments having better established infrastructures and policies geared towards increasing entrepreneurships, the Asian counterparts of this study focus a large amount of money towards this making them the preferred choice for entrepreneurs who need capital to begin. In China , up to \$56 billion was allocated just towards the financing of mass entrepreneurships from 2013 to 2016 (Reshetnikova, 2018; Wu, 2018).

Proposition 4: Nations that provide adequate access to public and private funding will encourage more entrepreneurs to start up than those that do not.

\section{Labor force population and R\&D employees}

Many entrepreneurial activities require semi-skilled and some highly skilled employees with technical know-how and since the cost of relocating employees and rising labor costs are generally unfavorable, entrepreneurs will settle within proximity to a labor market according to the needs of their business. Also considering that spin-off and spillover companies are pioneered by employees of existing firms, a large labor population will likely give rise to a large number of entrepreneurs who breakaway(Naudé, 2017). The largest labor market in this study, in fact in the world is China at 780839000 workers while the smallest is Botswana at 1080 000.The distribution shows that these figures are proportionally spread according to population and therefore do not give any clear interpretations. The number of R\&D researchers and technicians will give the number of people with special skills that can contribute to the innovative edge of companies and enterprises. Technologically advanced countries have more of these : Korea has 7498 per million and Malaysia 2397 per million, while other countries like Uganda and Ethiopia have a smaller number in proportion to their large populations of 28 and 91 respectively, suggesting that tech innovation is still in its infancy. Countries with proportionally high number such as South Africa, China and Algeria with 492, 1225 and 819 respectively are in the midst of developing innovation and tech fields of study and business which is more and more attractive to native and foreign entrepreneurs as prime location choices. Industries are in their prime with market share up for grabs, the ideal situation for entrepreneurs.

Proposition 5: Countries that have large populations of skilled employees in relevant fields will give entrepreneurs access to talented innovators and a better chance of survival and growth. 
International Journal of Social Science and Economic Research

ISSN: $2455-8834$

Volume:05, Issue:10 "October 2020"

\section{Government Programs that support entrepreneurship}

A significant portion of new ventures are financed by entrepreneur's personal savings and assistance from family and friends, however in the last decades governments believed an increase in entrepreneurial activity could lead to economic development and so began deliberate actions to support them(Audretsch, 2018; Audretsch et al., 2006). In countries where this is the case, there was a surge in the number of entrepreneurs. Such countries identified by the data are China, S. Korea, India, Algeria, Ethiopia all of which present the most sufficient government programs offering support to new ventures which include training, finance and allocated office space. In addition to this governments may allocate special regions within a country added incentives for certain types of entrepreneurs therefore enticing then to choose these locations over other places within one country. The ability for a government to provide these strongly depends on stability of the government, the availability of funding and to what extent it considers entrepreneurship to be important in its national strategy. Therefore, countries where all three factors align, the result will be higher entrepreneurial activity(Wu, 2018).

Proposition 6: Governments that facilitate entrepreneurial activity by actively supporting entrepreneurs will witness large populations of entrepreneurs in their countries.

\section{Access to affordable amenities}

(Atiase et al., 2018) and (Naudé, 2011) made it clear that entrepreneurs need several amenities to support their new innovative business models. These include reliable and affordable electricity and internet. Asian countries have the benefit of highly advanced infrastructures for both and can seamlessly provide these on most of the surface area of their nations. In the African countries surveyed, affordable electricity and ICT infrastructures is ranked to be averagely sufficient 2.99 to 3.33 meaning it may not be readily available to everyone at any time. The difference in the rankings is wide with Asian countries being ranked as highly sufficient 3.49 to 4.21 . This can explain the prevalent presence of mostly replicative entrepreneurs in Africa who make minimal use of tech and innovation in their business compared to Asian entrepreneurs who dominantly are making use of energy and internet(Acs \& Sanders, 2012; Reshetnikova, 2018) to solve problems in new and innovative ways.

Proposition 7: Access to amenities needed to start innovative ventures will determine how many entrepreneurs will be able to enter, survive and grow in the market.

\section{Entrepreneurial Ecosystem}

The entrepreneurial ecosystem encompasses many of the factors mentioned here, but based on institutional theory (Bruton, Ahlstrom, \& Li, 2010), formal institutions in the public sector were singled out to address some specific economic environment pre-requisites that may attract or repel entrepreneurs from certain areas. Several rankings were studied to determine the levels of 


\section{International Journal of Social Science and Economic Research}

ISSN: $2455-8834$

Volume:05, Issue:10 "October 2020"

corruption that entrepreneurs may need to overcome, how easy it is to do business within countries, the amount of time it takes to start a business including the number of days taken up by government procedures for approval. Of the countries surveyed it seems there is parity in the general levels of corruption on both continents with S. Korea and Botswana being the least corrupt and Uganda and Thailand being the most corrupt. Unfortunately, entrepreneurs will have to deal with corrupt practices regardless of location. Asia ranked better in ease of doing business with Korea being the best $\left(5^{\text {th }}\right)$, while Africa seems to have tougher barriers to entrepreneurship with Ghana ranking the worst $\left(118^{\text {th }}\right)$

Furthermore, Africa has more procedures on average required to register a business, which consequently means they take much longer times and governments take up a large portion of that time. This naturally can frustrate entrepreneurs, and reduces the number of aspirants that can make it to the final process. This suggest that the overall entrepreneurial ecosystem in Asia, is far more conducive to entrepreneurial activities and makes it easy for new market-entrants to join, while that of Africa appears to give aspiring entrepreneurs a tough time and can easily dishearten them. Entrepreneurs in this case may be drawn to places where the amount of red-tape needed to be navigated is minimal (Chowdhury, Terjesen, \& Audretsch, 2015).

Proposition 8: Countries where formal and informal institutions are well developed offer a better environment for entrepreneurs to compete fairly in the market.

\section{Protection of IPR}

The safeguarding of intellectual property and related property rights is a major concern to $21^{\text {st }}$ century entrepreneurs (Livramento, Foray, \& CHt, 2007). It puts inventors at ease to know that their innovations and inventions will be protected by the law against theft or unlawful reproduction. In both regions it shows there is equally distributed levels of protection of property rights. There is no clear distinction as to why countries provide better protections than others but, in both Asia, and Africa the countries providing the most sufficient protection are India, Indonesia and China at 3.34, 3.24 and 3.20, Uganda and Ghana at 3.09 and 3. Location wise both regions offer satisfactory laws to protect against theft of IP and offer sufficient assistance to entrepreneurs in regards to patent and copyright protections.

Proposition 9: More entrepreneurial activity can be encouraged when entrepreneurs know their rights and innovations can be protected by law.

\section{Government policies}

Regardless of whether governments can allocate office space or funding for entrepreneurs, if national strategy promotes entrepreneurship, this encourages more people to choose such countries to settle in for business. This boils down to whether government considers entrepreneurs as a vital structure of the economy that can positively contribute to employment, 


\section{International Journal of Social Science and Economic Research}

ISSN: $2455-8834$

Volume:05, Issue:10 "October 2020"

poverty reduction and economic growth. It seems the majority of the Asian countries pursue policies which not only favor but also encourage entrepreneurial activity. China, India, Korea and Indonesia scored high on the scale of sufficiency and literature supports that particularly in China and India there are various national economic policies geared towards increasing the total entrepreneurial activity of these countries by encouraging more and more citizens to create innovative businesses ( $\mathrm{Wu}, 2018)$. However by contrast one school of thought of studies centered in Africa, (Adusei, 2016) ,suggested that entrepreneurship may not lead to the much needed economic growth of some nations and it seems government policies do not actively support entrepreneurs, even though they do not discourage them either. One of most developed countries in Africa, South Africa, only provides 2.10 on a scale of 5 sufficient support to entrepreneurs through government policies. Many of the African countries have slightly below or above average scores of 2.75, 2.62, 2.29 and 2.45 for Algeria, Ethiopia, Ghana and Botswana respectively. In these countries more incentives and advantages are given to large firms and manufacturing and in some cases mining companies but fewer advantages are offered to startup firms, even tech-based ones. These disadvantages make these countries harder for entrepreneurial ventures to begin and survive and result in lower total numbers of entrepreneurs of new innovative businesses.

Proposition 9: Countries where national policies that actively support and facilitate entrepreneurial activity will consequently have more entrepreneurs than countries that do not

\section{Practical Implications of the research evidence}

The evidence surveyed two regions that are generally at different stages in their development. It appears in many of the factors chosen in this studies Asian countries provided higher levels of assistance and support for entrepreneurship and also had larger populations of entrepreneurs. It shows the most important factors leading to these countries being more entrepreneurial than the African counterparts in this paper are larger economies and more advanced technologies which offer more opportunities to start-up ventures and give them enough support to start and grow. The large populations in some of the Asian countries, although they do not directly have an influence on the TEA, they lead a larger number of people who will engage in entrepreneurship as does a societal culture that encourages it. Governments in these countries provide stable and fiscally feasible economic conditions for entrepreneurs. There are also more educated people which give these countries a bigger pool of talented entrepreneurs but also a skilled labor force. The presence of large and famous companies whether local or foreign multinationals, coupled with highly ranked universities means there is a rich and almost constant supply for knowledge that is continuously being built upon to create new business models that disrupt the economic status quo and lead to high-tech economies led by a new generation of entrepreneurs. These 


\section{International Journal of Social Science and Economic Research}

ISSN: $2455-8834$

Volume:05, Issue:10 "October 2020"

reasons all contribute to the notion that Asia is in fact more entrepreneurial than Africa, and will be a more popular choice for entrepreneurs.

The data collected from African countries shows that there is definitely a significant amount of entrepreneurial activity, and previous studies suggest most of it is mainly trade and natural resource oriented. The more developed countries on the continent offer much greater support resources for entrepreneurs, encouraging innovative and tech companies as well. The populations are generally smaller than Asia, but even in more populated countries, the number of entrepreneurs is not significantly higher. It appears societal norms do not particularly prefer entrepreneurship over traditional jobs but rather consider it remedy in the case one is unable to find a job, and less advanced infrastructure makes it a challenge for those entrepreneurs who attempt. It seems government policy does not discourage entrepreneurship but offers minimal support in terms of policies and funding to entrepreneurs. There are arguably smaller populations of especially talented researchers and technicians particularly in STEM fields, with fewer highly ranked universities and fewer innovative tech companies that can be knowledge sources. All these contribute to the phenomenon of having fewer entrepreneur populations. The less techinclined economies that largely still rely on natural resources have a smaller demand for internet and tech companies which make these countries particularly unattractive for immigrant entrepreneurs with newer business models. It seems most entrepreneurial activity here is geared towards manufacturing, mining and production of raw minerals and buying and selling of goods, this can make it a popular choice for entrepreneurs whose businesses focus on these aspects of the economy. But for innovation driven entrepreneurs the obstacles and lack of market makes Africa a poor choice, for now.

\section{Conclusions}

The main aim of this study was to determine what influenced the location decisions of entrepreneurs and to try and differentiate what caused some places to be more entrepreneurial than others. For this we compiled the economic indicators from 12 countries in Asia and Africa and consulted with previous studies done on this and related topics. It was found that entrepreneurs favor, their home countries, place of work or education and more specifically countries that offer them knowledge to build upon, better opportunities for growth and market for their businesses. They will choose places where government policies promote entrepreneurship and provide access to affordable infrastructures, government and private funding and where societies have a positive opinion on entrepreneurship. It therefore stands to reason that countries where these conditions are more prevalent and widespread will have higher levels of entrepreneurial activity whereas places where conditions are still stringent and many necessities remain insufficient there will consequently be less.

\section{Limitations and Recommendations for further study}




\section{International Journal of Social Science and Economic Research}

ISSN: $2455-8834$

Volume:05, Issue:10 "October 2020"

This paper was written using secondary data of economic indicators and previous literature. This may mean the scope of the information used to make several conclusions may be generalized for entire nations and do not take into consideration the regional differences within those countries. It is recommended that further study on this topic may consider the internal or intra-continental differences to further comb down the factors that affect the entrepreneurs' location decision. Furthermore, the countries chosen in this sample were simply chosen as a convenience sample according to data which was made available by the various data bank institutions. A more representative sample of each continent may be considered and a scientific or mathematical model may be applied to effectively evaluate and rank factors according to their significance.

\section{References}

Acs, Z. J., \& Sanders, M. (2008). Intellectual property rights and the knowledge spillover theory of entrepreneurship. Retrieved from

Acs, Z. J., \& Sanders, M. (2012). Patents, knowledge spillovers, and entrepreneurship. Small Business Economics, 39(4), 801-817.

Adusei, M. (2016). Does entrepreneurship promote economic growth in Africa? African Development Review, 28(2), 201-214.

Agarwal, R., Audretsch, D., \& Sarkar, M. (2010). Knowledge spillovers and strategic entrepreneurship. Strategic Entrepreneurship Journal, 4(4), 271-283.

Agarwal, R., Echambadi, R., Franco, A. M., \& Sarkar, M. B. (2004). Knowledge transfer through inheritance: Spin-out generation, development, and survival. Academy of Management journal, 47(4), 501-522.

Anthony, A. T., \& Adegbola, O. (2017). NIGERIAN ENTREPRENUERS AND THEIR INTELLECTUAL PROPERTIES-A PERSPECTIVE VIEW. Theme: "Entrepreneurship and the Knowledge Economy", 496.

Asongu, S. A., Nwachukwu, J. C., \& Orim, S.-M. I. (2018). Mobile phones, institutional quality and entrepreneurship in Sub-Saharan Africa. Technological Forecasting and Social Change, 131, 183-203.

Atiase, V. Y., Mahmood, S., Wang, Y., \& Botchie, D. (2018). Developing entrepreneurship in Africa: investigating critical resource challenges. Journal of Small Business and Enterprise Development.

Audretsch, D. B. (2018). Entrepreneurship, economic growth, and geography. Oxford Review of Economic Policy, 34(4), 637-651. doi:10.1093/oxrep/gry011 


\section{International Journal of Social Science and Economic Research}

ISSN: $2455-8834$

Volume:05, Issue:10 "October 2020"

Audretsch, D. B., Keilbach, M. C., \& Lehmann, E. E. (2006). Entrepreneurship and economic growth: Oxford University Press.

Autio, E., Nambisan, S., Thomas, L. D. W., \& Wright, M. (2018). Digital Affordances, Spatial Affordances, and the Genesis of Entrepreneurial Ecosystems. Strategic Entrepreneurship Journal, 12(1), 72-95.

Benjamin, P., Bhorat, H., \& Cheadle, H. (2010). The cost of "doing business" and labour regulation: The case of South Africa. International Labour Review, 149(1), 73-91.

Bloom, N., \& Van Reenen, J. (2010). Why do management practices differ across firms and countries? Journal of economic perspectives, 24(1), 203-224.

Brixiová, Z., \& Kangoye, T. (2016). Gender and constraints to entrepreneurship in Africa: New evidence from Swaziland. Journal of Business Venturing Insights, 5, 1-8.

Bruton, G. D., Ahlstrom, D., \& Li, H. L. (2010). Institutional theory and entrepreneurship: where are we now and where do we need to move in the future? Entrepreneurship theory and practice, 34(3), 421-440.

Buenstorf, G., \& Klepper, S. (2010). Why does entry cluster geographically? Evidence from the US tire industry. Journal of Urban Economics, 68(2), 103-114.

Burger, L., O'Neill, C., \& Mahadea, D. (2005). The impact of previous knowledge and experience on the entrepreneurial attitudes of Grade 12 learners. South African journal of education, 25(2), 89-94.

Castillo, R. (2014). Feeling at home in the "Chocolate City": an exploration of place-making practices and structures of belonging amongst Africans in Guangzhou. Inter-Asia Cultural Studies, 15(2), 235-257.

Chowdhury, F., Terjesen, S., \& Audretsch, D. (2015). Varieties of entrepreneurship: institutional drivers across entrepreneurial activity and country. European Journal of Law and Economics, 40(1), 121-148.

Dahl, M. S., \& Sorenson, O. (2009). The embedded entrepreneur. European Management Review, 6(3), 172-181.

Dahl, M. S., \& Sorenson, O. (2012). Home Sweet Home: Entrepreneurs' Location Choices and the Performance of Their Ventures. Management Science, 58(6), 1059-1071.

Dau, L. A., \& Cuervo-Cazurra, A. (2014). To formalize or not to formalize: Entrepreneurship and pro-market institutions. Journal of Business Venturing, 29(5), 668-686. 


\section{International Journal of Social Science and Economic Research}

ISSN: 2455-8834

Volume:05, Issue:10 "October 2020"

Delgado, M., Porter, M. E., \& Stern, S. (2010). Clusters and entrepreneurship. Journal of economic geography, 10(4), 495-518.

Devezas, T., \& Sarygulov, A. (2017). Industry 4.0: Springer.

Dumais, G., Ellison, G., \& Glaeser, E. L. (2002). Geographic concentration as a dynamic process. Review of economics and Statistics, 84(2), 193-204.

Egeln, J., Gottschalk, S., \& Rammer, C. (2004). Location Decisions of Spin-offs from Public Research Institutions. Industry and Innovation, 11(3), 207-223. doi:10.1080/1366271042000265384

Ekpe, I., Mat, N. B., \& Razak, R. C. (2010). The Effect of Microfinance Factors on Women Entrepreneurs' Performance in Nigeria: A Conceptual Framework International Journal of Business and Social Science, 1(2).

Etemad, H., \& Wright, R. W. (2003). Globalization and entrepreneurship: policy and strategy perspectives: Edward Elgar Publishing.

Feldman, M. P., \& Francis, J. (2002). The entrepreneurial spark: Individual agents and the formation of innovative clusters Complexity and industrial clusters (pp. 195-212): Springer.

Ferreira, J. J., \& Fernandes, C. I. (2015). Entrepreneurship and Location: The Cultural Differences Between Two Countries. In M. Peris-Ortiz \& J. M. Merigó-Lindahl (Eds.), Entrepreneurship, Regional Development and Culture: An Institutional Perspective (pp. 23-34). Cham: Springer International Publishing.

Figueiredo, O., Guimaraes, P., \& Woodward, D. (2002). Home-field advantage: location decisions of Portuguese entrepreneurs. Journal of Urban Economics, 52(2), 341-361.

GEM. (2019). Entrpreneuerial Framework Conditions. from Global Entrepreneurship Research Association https://www.gemconsortium.org/data/sets?id=nes

Ghio, N., Guerini, M., Lehmann, E. E., \& Rossi-Lamastra, C. (2015). The emergence of the knowledge spillover theory of entrepreneurship. Small Business Economics, 44(1), 1-18. doi:10.1007/s11187-014-9588-y

Glaeser, E. L., Kerr, W. R., \& Ponzetto, G. A. M. (2009). Clusters of Entrepreneurship. Retrieved from National Bureau of Economic Research, Inc: https://ideas.repec.org/p/nbr/nberwo/15377.html

Halkias, D., Nwajiuba, C., Harkiolakis, N., \& Caracatsanis, S. M. (2011). Challenges facing women entrepreneurs in Nigeria. Management Research Review, 34(2), 221-235. 


\section{International Journal of Social Science and Economic Research}

ISSN: $2455-8834$

Volume:05, Issue:10 "October 2020"

He, C., Lu, J., \& Qian, H. (2019). Entrepreneurship in China. Small Business Economics, 52(3), 563-572.

Henry, C. (2007). Entrepreneurship in the creative industries: An international perspective: Edward Elgar Publishing.

Herrera-Echeverri, H., Haar, J., \& Estévez-Bretón, J. B. (2014). Foreign direct investment, institutional quality, economic freedom and entrepreneurship in emerging markets. Journal of Business Research, 67(9), 1921-1932.

Isenberg, D. J. (2010). How to start an entrepreneurial revolution. Harvard business review, $88(6), 40-50$.

Johnson, S., Kaufmann, D., \& Shleifer, A. (1997). Politics and entrepreneurship in transition economies. Available at SSRN 1117620.

Klapper, L., Amit, R., Guillén, M. F., \& Quesada, J. M. (2007). Entrepreneurship and firm formation across countries: The World Bank.

Klepper, S. (2001). Employee startups in high-tech industries. Industrial and corporate change, 10(3), 639-674.

Klepper, S., \& Sleeper, S. (2000). Entry by spinoffs. Working paper. Pittsburgh.

Kolympiris, C., Kalaitzandonakes, N., \& Miller, D. (2015). Location choice of academic entrepreneurs: Evidence from the US biotechnology industry. Journal of Business Venturing, 30(2), 227-254. doi:https://doi.org/10.1016/j.jbusvent.2014.02.002

Liu, C. Y., Ye, L., \& Feng, B. (2019). Migrant Entrepreneurship in China: Entrepreneurial Transition and Firm Performance. Small Business Economics, 52(3), 681-696.

Livramento, I. M. H., Foray, D., \& CHt, L. (2007). Does IPR protection affect high growth entrepreneurship? A cross-country empirical examination. Retrieved from

Mamun, A. A. (2016). Access to credit, education and entrepreneurial competencies: A study among women micro-entrepreneurs in Malaysia. Vision, 20(3), 159-168.

Michelacci, C., \& Silva, O. (2007). Why So Many Local Entrepreneurs. The Review of Economics and Statistics, 89(4), 615-633.

Naudé, W. (2011). Entrepreneurship is not a binding constraint on growth and development in the poorest countries. World Development, 39(1), 33-44.

Naudé, W. (2017). Entrepreneurship, education and the fourth industrial revolution in Africa. 


\section{International Journal of Social Science and Economic Research}

ISSN: $2455-8834$

Volume:05, Issue:10 "October 2020"

Nieman, G., \& Pretorius, M. (2004). Managing growth: A guide for entrepreneurs: Juta and Company Ltd.

Prince, W., \& Fantom, N. (2014). World development indicators 2014 (English). Retrieved from Washington, DC:

http://documents.worldbank.org/curated/en/752121468182353172/World-developmentindicators-2014

Reshetnikova, M. (2018). Innovation and entrepreneurship in China. European Research Studies Journal, 21, 506-515.

Reuber, A. R., \& Fischer, E. (2011). International entrepreneurship in internet-enabled markets. Journal of Business Venturing, 26(6), 660-679.

Sarkar, A. (2016). Startup India-A New Paradigm for Young Entrepreneurs (A Conceptual Study). Available at SSRN 2835322.

Schwab, K. (2015). World economic forum. Global Competitiveness Report (2014-2015) Retrieved http://www3. weforum. org/docs/WEF_GlobalCompetitivenessReport_2014-15. $p d f$.

Siegel, D. S., \& Wright, M. (2015). University technology transfer offices, licensing, and startups. Chicago handbook of university technology transfer and academic entrepreneurship, $1-40$.

Somoye, R. O. C. (2013). The impact of finance on entrepreneurship growth in Nigeria: A cointegration framework. ACRN Journal of Entrepreneurship Perspectives, 2(2), 21-45.

Stuart, T., \& Sorenson, O. (2003). The geography of opportunity: spatial heterogeneity in founding rates and the performance of biotechnology firms. Research policy, 32(2), 229253.

TheKauffmanInstitute. (2019). Indicators of entrepreneuership Retrieved from https://indicators.kauffman.org/

Wellalage, N. H., Locke, S., \& Samujh, H. (2019). Firm bribery and credit access: evidence from Indian SMEs. Small Business Economics, 1-22.

WorldBank. (2019). Indicators. Retrieved from Washington DC: https://data.worldbank.org/

Wu, Q. (2018). The Campaign of Mass Entrepreneurship and Innovation. In C.-T. Foo (Ed.), Handbook of Chinese Management (pp. 1-13). Singapore: Springer Singapore. 


\section{International Journal of Social Science and Economic Research}

ISSN: $2455-8834$

Volume:05, Issue:10 "October 2020"

Yeung, H. W.-c. (2009). Transnationalizing entrepreneurship: a critical agenda for economic geography. Progress in Human Geography, 33(2), 210-235.

Zhang, M. Y., \& Dodgson, M. (2014). High-tech entrepreneurship in Asia: Innovation, industry and institutional dynamics in mobile payments: Edward Elgar Publishing.

Zou, L., \& Liang, Q. (2015). Mass entrepreneurship, government support and entrepreneurial cluster: Case study of Junpu Taobao Village in China. Scholars Journal of Economics, Business and Management, 2(12), 1185-1193.

\section{Appendix 1: Literature survey of locational factors}

\begin{tabular}{|c|c|c|}
\hline Factor & Description & Literature \\
\hline $\begin{array}{l}\text { Birthplace, } \\
\text { influence }\end{array}$ & $\begin{array}{l}\text { Entrepreneurs are most likely to } \\
\text { set up businesses in the } \\
\text { countries of their birth, therefore } \\
\text { larger populations will exhibit } \\
\text { large numbers of entrepreneurs. } \\
\text { Socio-cultural norms can either } \\
\text { encourage or discourage } \\
\text { entrepreneurship. }\end{array}$ & $\begin{array}{l}\text { (Kolympiris, Kalaitzandonakes, } \\
\text { \& Miller, 2015) } \\
\text { (Buenstorf \& Klepper, 2010; } \\
\text { Dahl \& Sorenson, 2012; Ferreira } \\
\text { \& Fernandes, 2015; Michelacci } \\
\text { \& Silva, 2007) }\end{array}$ \\
\hline Proximity to Knowledge source & $\begin{array}{l}\text { Existing companies and } \\
\text { Universities exist as parent } \\
\text { organizations that can provide } \\
\text { R\&D and access to } \\
\text { opportunities for startups, spin- } \\
\text { offs and spillover firms }\end{array}$ & $\begin{array}{l}\text { (Agarwal et al., 2004; Audretsch } \\
\text { et al., 2006; Egeln, Gottschalk, } \\
\& \text { Rammer, 2004; Feldman \& } \\
\text { Francis, 2002; Siegel \& Wright, } \\
\text { 2015) }\end{array}$ \\
\hline $\begin{array}{l}\text { Proximity to similar or related } \\
\text { organizations }\end{array}$ & $\begin{array}{l}\text { Entrepreneurial clusters may } \\
\text { lead to companies in the same of } \\
\text { closely related businesses to } \\
\text { locate within the same } \\
\text { geographical space in order to } \\
\text { collaborate }\end{array}$ & $\begin{array}{l}\text { (Agarwal et al., 2010; Audretsch } \\
\text { et al., 2006; Zou \& Liang, 2015) }\end{array}$ \\
\hline Finance & $\begin{array}{l}\text { Entrepreneurs will tend to locate } \\
\text { where they have a good chance } \\
\text { of receiving financial support or } \\
\text { where investors or government } \\
\text { has allocated }\end{array}$ & $\begin{array}{l}\text { (Atiase et al., 2018; Mamun, } \\
\text { 2016; Reshetnikova, 2018; } \\
\text { Somoye, 2013; Wellalage, } \\
\text { Locke, \& Samujh, 2019) }\end{array}$ \\
\hline Labor Force, Education & $\begin{array}{l}\text { Where there are large } \\
\text { populations of highly skilled and } \\
\text { educated workers, there will be } \\
\text { a large number of entrepreneurs } \\
\text { because they will leave their } \\
\text { jobs to start up their own firms, }\end{array}$ & $\begin{array}{l}\text { (Benjamin, Bhorat, \& Cheadle, } \\
\text { 2010; Siegel \& Wright, 2015; } \\
\text { Yeung, 2009) }\end{array}$ \\
\hline
\end{tabular}


International Journal of Social Science and Economic Research

ISSN: 2455-8834

Volume:05, Issue:10 "October 2020"

\begin{tabular}{|l|l|l|}
\hline & $\begin{array}{l}\text { and other entrepreneurs may } \\
\text { come there to take advantage of } \\
\text { the skilled population }\end{array}$ & \\
\hline Government Programs & $\begin{array}{l}\text { In countries where governments } \\
\text { actively provide finance and } \\
\text { other resources for } \\
\text { entrepreneurs }\end{array}$ & $\begin{array}{l}\text { (Bloom \& Van Reenen, 2010; } \\
\text { Isenberg, 2010; Reshetnikova, } \\
2018 ; \text { Wu, 2018) }\end{array}$ \\
\hline $\begin{array}{l}\text { Access to affordable reliable } \\
\text { amenities like Internet and } \\
\text { electricity }\end{array}$ & $\begin{array}{l}\text { Innovative entrepreneurs need } \\
\text { internet and electricity to be able } \\
\text { to reach full potential and some } \\
\text { countries provide these better } \\
\text { than others }\end{array}$ & $\begin{array}{l}\text { (Atiase et al., 2018; Autio et al., } \\
2018 ; \text { Naudé, 2011, 2017) }\end{array}$ \\
\hline $\begin{array}{l}\text { Dynamic } \\
\text { ecosystem }\end{array}$ & $\begin{array}{l}\text { In countries where there is well } \\
\text { established supply chains and } \\
\text { wealthy customers entrepreneurs } \\
\text { with good business models have } \\
\text { limitless opportunities to expand } \\
\text { and grow their businesses }\end{array}$ & $\begin{array}{l}\text { (Asongu, Nwachukwu, \& Orim, } \\
\text { 2018; Atiase et al., 2018; } \\
\text { et al., 2019) }\end{array}$ \\
\hline $\begin{array}{l}\text { Protection of IPR } \\
\text { Much R\&D is the corner stone 2010; Wellalage } \\
\text { of new entrepreneurs and they } \\
\text { will choose to settle where their } \\
\text { IP can be protected by law }\end{array}$ & $\begin{array}{l}\text { (Acs \& Sanders, 2008, 2012; } \\
\text { Anthony \& Adegbola, 2017; } \\
\text { Sarkar, 2016) }\end{array}$ \\
\hline $\begin{array}{l}\text { Entrepreneurs can thrive in } \\
\text { stable political environments } \\
\text { and even more when } \\
\text { government policy encourages } \\
\text { ownership if businesses }\end{array}$ & $\begin{array}{l}\text { (Chowdhury et al., 2015; Zou \& } \\
\text { Liang, 2015) }\end{array}$ \\
\hline
\end{tabular}

